Kateryna Miliutina,

Doctor of Psychology, professor,

Department of Developmental Psychology, Taras Shevchenko National University of Kyiv, 2, Hlushkova Str., Kyiv, Ukraine

\title{
IMPACT OF INFORMAL ACTIVITIES ON SOCIALIZATION OF ADOLESCENTS WITH VISUAL IMPAIRMENT
}

The article is aimed at revealing the difference of socialization of children with visual impairment and the level of the influence of club activities on the success of their social adaptation. The research method complex includes the following diagnostic techniques: the constructive drawing of the person by means of geometrical figures (TIGER), a technique of diagnostics of social and psychological adaptation by Rogers-Dymond, a technique of level of social frustration by L. Wasserman, Spielberg's technique - determination of level of anxiousness, a multi-level personal questionnaire "Adaptability" (MLPQ-A). The study involved 71 adolescents: 32 respondents with visual impairment and 38 school students without any physical disorders.13 adolescents with visual impairment were engaged to informal activities (the work of a psychological club) and formed the experimental group. The indicator of satisfaction with one's health and working capacity in children with visual impairments has been revealed for the following characteristics: adaptability, self-perception, acceptance, emotional conformity, communication potential and behaviour regulation. The results obtained with the constructive drawing method confirmed the statistical data and made it possible to characterize adolescents with visual impairments to a great extent. The level manifestation of moral normativity indicator is common for both groups of the surveyed; it shows the right perception of one's place and role in a group. This characteristics correlates authentically with the satisfaction with life in children with visual impairment. Thus, it can be assumed that in a comfort communication zone, among the adolescents with the same characteristic, participants of the experimental group feel more comfortable. The adolescents from the control group are characterized as self-sufficient, emotionally stable, they tend to be strict towards themselves and others. In the experimental group, the type "initiator" or so-called dreamer, is a predominant one. The drawings of adolescents from the experimental group seem to be undone, which reflects the specificity of reactive states. However, it is just a hypothesis, one needs to carry out the detailed research not just in the sphere of psychology, but also psychiatry to prove it. Adolescents with visual impairment draw in a unique way: their pictures are placed in the upper left part of the sheet, and their pictures are small or medium as a rule. Thus, this feature shows the tendency for psychological escape from reality in the world of fantasy. The participation in informal education contributes to the development of the ability for adaptation, better self-perception, emotional conformity and communication potential in adolescents with visual impairment.

Keywords: self-assessment, self-concept, adaptation, informal education, psychological club.

Подано до редакиії 01.09.2016

УДК: 159.922 .62

Віра Юрї̈вна Помилуйко, кандидат психологічних наук, докторант, Наиіональний педагогічний університет імені М. П. Драгоманова, вул. Пирогова, 9, м. Київ, Украӥна

\section{ШЛЯХ ДО ЗРІЛОСТІ ЧЕРЕЗ ЖИТТЕВІ КРИЗИ ДОРОСЛИХ}

У статті розглянуто вікові кризи в дорослому віщі, їх різновиди, наслідки та вектори розвитку. Визначено позитивну і негативну симптоматику, щзо виникає в період зрілості особистості в процесі подолання основних життєвих криз. Виявлено, щзо в описі криз дорослого періоду изентральне місце відведено перегляду основних ияілей $і$ життєвих орієнтирів особистості, щзо є загальною характеристикою криз дорослості.

Ключові слова: вікові кризи, вектори розвитку, дорослість, переживання, різновиди життєвих криз, фрустрації.

У процесі онтогенезу людина долає ряд вікових періодів, що мають свої характерні якісні особливості. Одним із таких періодів є дорослість, що характеризується інтенсивним розвитком людини, розкриттям їі особистісного потенціалу, можливостей і здібностей, досягненнями у професійній кар'єрі та сімейному житті. Майже всі дослідники дорослого віку відміча- ють недостатню вивченість цього періоду, суперечливість думок та багатоваріантність суджень. Так, I. Солоднікова зазначає: «Той факт, що вікові періоди наступні за шкільним залишаються багато в чому «білою плямою» для вітчизняної вікової та соціальної психології, не в останню чергу пояснюється тим, що після закінчення школи не існує єдиного для всіх 
інституту соціалізації. Однак, дорослість потребує вивчення хоча б тому, що це найбільш тривалий віковий період в життєвому циклі $[9$, с. 157]».

Розвиток людини у час дорослості залежить від успішного розв'язання проблем попередніх етапів онтогенезу. Розвиток особистості в дорослому віці напряму пов'язаний із кризовими явищами цього періоду. Вікові кризи в дорослому віці можна охарактеризувати як перехід до нового етапу розвитку, що характеризується різкими психологічними змінами (y світогляді людини, в пізнавальній $і$ діяльнісній сферах, соціальному статусі, ставленні до себе). Вони зумовлюються руйнуванням звичної ситуації розвитку та виникненням іншої, більш адекватної психологічному розвиткові людини на відповідному етапі. Тривалість, форми перебігу, гострота проходження вікових криз варіюються в залежності від індивідуальнотипологічних особливостей людини, іiі соціальних умов. Кризовий стан можна вважати перехідним явищем, що спонукає до самовдосконалення, саморозвитку особистості.

Більшість дослідників (О. Байєр, Е. Еріксон,

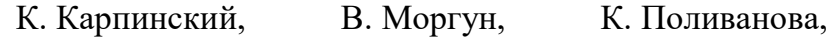
В. Слободчиков, О. Солдатова, Т. Титаренко, Д. Шарп, Г. Шихі та ін.) вважають вікові кризи існування людини завершенням певного етапу психічного розвитку індивіда.

Мета статті полягає у теоретичному аналізі векторів розвитку вікових криз особистості в дорослому віці, виокремленні позитивної і негативної симптоматики основних криз дорослості.

Різні кризи дорослого віку, хоча і мають свої особливості, типовими їх проявами психологи вважають паніку, тривожність, підвищену чутливість до критики, актуалізацію фобій, переоцінку сенсу життя та зміну ієрархії мотивів і ціннісних орієнтацій, що призводять до розлучень, а також сварок із рідними у сімейному житті, звільнень із роботи - у професійній діяльності. Т. Дзюба і О. Коваленко обгрунтовують цей факт тією обставиною, що суб'єкт розуміє власну неспроможність продукувати поведінку щодо раніше сформованих стратегій, відчуває дискомфорт та психологічну напругу. Отже, створюється кризова ситуація, що вимагає від людини значної зміни уявлень про світ і про себе за короткий проміжок часу. Автори стверджують, що у надзвичайно мінливих інформаційно-насичених умовах життєвий простір дорослої особистості доволі часто супроводжується розмаїттям кризових станів, значуще місце серед яких займає життєва криза особистості [5, с. 158-160].

У сучасній психології виділяють такі різновиди життєвих криз: біологічні та біографічні (Р. Ахмеров, Л. Сафонова), соиіальні й особистісні (Ю. Кисельов, В. Лукін-Григор'єв), нормативні кризи травматичного або невротичного характеру (Е. Еріксон, К. Стренгер, А. Руттенберг); внутрішні та зовнішні (Л. Шнейдер); поверхневі, середні $і$ глибинні (М. Варій, Т. Титаренко) тощо. У сучасній психології існу- ють різні класифікації життєвих криз. Так, Є. Варбан узагальнює відомі класифікації життєвих криз дорослості за такими критеріями:

1) вік (кризи розвитку): криза 30 -ти років; криза «середини» життя; криза похилого віку;

2) тривалість: мікрокриза - кілька хвилин; короткочасна - до 4-6 тижнів; довготривала - до 1 го року;

3) результативність: конструктивні; деструктивні;

4) за діяльнісним критерісм: криза операційного аспекту життєдіяльності: «не знаю, як жити далі»; криза мотиваційно-цільової сторони життєдіяльності: «не знаю, для чого жити далі»; криза смислового аспекту життєдіяльності: «не знаю, навіщо взагалі жити далі»;

5) детермінованість: кризи, що викликані інтрапсихічними та ситуативними факторами;

6) за критерісм складності: прості кризи, що спричинені однією подією; багатовимірні кризи, що торкаються практично всіх аспектів індивідуального життя особистості;

7) передбачуваність: передбачувані (нормативні); «ситуаційні» (ймовірнісні); проміжні [1, с. 122123].

Т. Титаренко різновидами життєвих криз, що переживає кожна особистість, вважає нормальні та анормальні [10, с. 91]. Нормальна криза, на думку автора, є переходом від одного вікового етапу до іншого, тоді як анормальна криза виникає у складних умовах, коли людина переживає важливі події у родинному, професійному, особистому житті, що раптово змінюють ії долю [10, с. 92]. В. Моргун зазначає, що кожен новий період вікового розвитку змінюється нормативними кризами дорослої особистості: криза молодості - «сім'я, покликання» (27-33 роки); криза дорослості - «визнання» (39-45 років); криза зрілості - «наставництво» (55-65 років); криза сенсу життя «мудрість і спокій» [6, с. 210]. Отже, можна зробити висновок, що не існує загальноприйнятої класифікації життєвих криз, їх види відрізняються в залежності від виокремлених авторами критеріїв.

У процесі проходження криз у дорослому віці виділяються два вектори розвитку: позитивна дезінтеграція, де криза стає механізмом змін і переходу на новий рівень розвитку, і негативна дезінтеграція, при якій криза супроводжується нарощуванням ознак дезадаптації. В. Поліщук наполягає на диференційованому підході до особистості у вікових кризах, сутність яких, на думку автора, полягає в організації особистісно зорієнтованих навчально-виховних впливів на розвиток позитивної симптоматики, а не на локалізацію негативних [7, с. 2]. Отже, накопичення позитивної симптоматики у період вікових криз допомагає швидко іï подолати. Крім того, Ф. Василюк 
зазначає, що людина у критичній життєвій ситуації справляється 3 психологічними труднощами за допомогою особливої внутрішньої діяльності, яку він називає переживанням. Автор виокремлює різні види переживань: гедоністичні (ігнорує наявну реальність, заперечує іiі, формує і підтримує ілюзію благополуччя); реалістичні (підкоряється принципу реальності, в основі якого лежить механізм терпіння); ціннісні (будує новий сенс життя, враховуючи при цьому життєві втрати); творчі (зберігає здатність свідомо шукати вихід із скрутного становища за допомогою самоформування, самотворення). 3 метою окреслення можливих поєднань типів критичних ситуацій (стрес, фрустрація, конфлікт, криза) і виокремлених типів переживань науковець скористався прийомом «типологічного множення» (за О. Генісаретським). Помноживши між собою типології критичної ситуації і переживань, науковець отримав поле 316 комбінаторних можливостей, які він розглядає за критерієм «успішності - неуспішності» [2, с. 105]. Ф. Василюк доводить, що переживання критичної ситуації може бути опосередковано переходом життєвого світу людини 3 одного стану в інший, в процесі якого відбуваються три взаємопов'язані процеси: сам перехід життєвого світу в новий стан; зміна статусу і типу критичної ситуації в зв'язку 3 цим переходом; змістовносмислова переробка подій вже в новому контексті [2, c. 113].

Отже, вікові кризи у дорослому віці супроводжуються важливими життєвими подіями: розлученням або втратою сім’ї; зміною фаху, місця роботи $і$ проживання, що також передбачає зміну важливих соціальних ролей людини: професійних, сімейних, міжособистісних тощо. Особистість дорослого віку, яка не подолала наслідків кризи, починає деградувати, у неї можуть 3'являтися шкідливі звички та різні види захворювань (алкоголізм, наркоманія або невроз, психосоматичні захворювання тощо). У таких людей формується феномен «безпорадності», що проявляється у відмові від творчих пошуків і зусиль при розв'язанні нових задач і проблем унаслідок попередніх фрустрацій. Отже, наслідки вікових криз у дорослому віці можуть призвести до втрати сенсу життя або деградації. Психологія дорослих орієнтована на життєвий досвід минулого, згідно з яким вони обирають стратегію щодо дій у майбутньому.

Таким чином, у процесі вікових життєвих криз механізмом змін і переходу на новий рівень розвитку стає позитивна дезінтеграція та домінуючий тип переживань, від яких залежить ступінь збереженості особистості після виходу із кризи. У період криз у дорослому віці людина потрапляє в критичну ситуацію, де зіштовхується 3 неможливістю реалізації внутрішніх потреб свого життя (мотивів, прагнень, ияінностей), що супроводжується гострим емоційним станом та переживаннями. У цей період ініціюється процес об'єднання внутрішніх підсистем матеріального, соціального і духовного «Я» у єдиний цілісний простір, і починається процес переоцінки всіх цінностей. Задоволення людиною найважливіших життєвих потреб не може бути усунено засобами, відомими їй із минулого досвіду, а вимагає прояву творчості та активності. Основним джерелом швидкого виходу особистості 3 вікових криз дорослості $€$ iї активність, постійний пошук використання своїх творчих талантів та прояву власних здібностей, самореалізація і саморозвиток. Отже, рушійною силою розвитку повинно виступати внутрішнє прагнення до особистого зростання і самовдосконалення, що активізують та урізноманітнюють діяльність людини, наповнюють життя певним сенсом.

Сучасні науковці вказують на різну кількість життєвих криз у дорослому віці. Різні автори (О. Гречаник, Т. Дзюба, О. Коваленко, Л. Пілецька) відмічають оригінальність у виокремленні життєвих криз дорослих Г. Шихі, що розглядає їх семирічну періодичність, а саме: 16 років - «виривання коренів»; 23 роки - «план на все життя»; 30 років - «корекція»; 37 років - «криза середини життя»; проблема 45 років - «відновлення або покірність». Визначені Г. Шихі вікові кризи пов'язані зі змінами ролей людини в процесі життя та стереотипами поведінки: «вічна дитина», «клозет», «транзит», «інтегратор», «квочка», «кар'єрист із підлагодженим сімейним життям». О. Гречаник робить узагальнення, що в світовій психологічній літературі різні автори визначають такі періоди вікових криз дорослого періоду: криза двадияти трьох років - людина стає дорослою, відповідальною за свої вчинки, починає будувати своє майбутнє паралельно на роботі й у родині; криза тридияти років - самоаналіз, підведення перших підсумків, відкриття нових можливостей власної особистості, бажання їх реалізувати; криза тридияти n'яти років - чоловіки й жінки відчувають, що час їх підганяє, прагнуть побудувати будь-що нове; криза сорока років - криза цінностей; криза n'ятдесяти років підготовка до виходу на пенсію; криза n'ятдесяти шести років - підведення підсумків, переоцінювання цінностей, пошук нового місця в житті [4, с. 36].

Погоджуємося 3 думкою О. Солдатової, що в описі криз дорослого періоду центральне місце відведено перегляду основних цілей і життєвих орієнтирів особистості, що $є$ загальною характеристикою криз дорослості. Автор зазначає, що у кризі переходу до ранньої дорослості (молодості) особистість визначає для себе максимально можливі цілі, далекі перспективи. У кризі переходу до середньої дорослості підбиваються перші підсумки, аналізуються власні досягнення на шляху до поставлених у період переходу до молодості цілей, людина шукає шанси виправити помилки та висуває нові завдання, корегує стратегію дій. Криза переходу до зрілості пов'язана, на переконання науковця, зі зверненням до внутрішнього «Я». Пошуки нових сенсів призводять через звернення до себе до більш високих цінностей, що супроводжуються набуттям духовності, гуманізму тощо [8, с. 60-61]. 
Iз урахуванням позицій таких науковців як В. Моргун, В. Слободчиков, О. Солдатова виокремлюємо такі основні кризи дорослого віку: криза входження у дорослість «власне Я та його реалізація» (20-23 роки); криза молодості «сім'я, покликання» (27-33 роки); криза середини життя «визнання» (39. 45 років); криза зрілості «наставництво» (55-65 років). Охарактеризуємо ці життєві кризи з визначенням позитивних і негативних симптомів їх прояву.

Криза входження у дорослість «власне Я та його реалізація» (20-23 роки) - перша нормативна криза дорослого віку. Мрії та сподівання юнацького віку та прагнення досягти певних вершин у кар'єрі та створенні сім’ї вимагають активної діяльності молодої людини. Цю кризу можна охарактеризувати як встановлення співвідношення між «Я - реальним» і «Я ідеальним», що передбачає індивідуалізацію, самореалізацію та відповідальність за власну поведінку. Позитивними симптомами цієї кризи В. Поліщук вважає гордість за власні досягнення, уміння самооцінювати, уміння самоконтролю, переживання власних успіхів або невдач, прагнення до самостійності, старанність, оптимізм. Негативними симптомами є дратівливість, хитрість, індивідуалізм, пристосовуваність; зарозумілість, заздрість, корисливість; недбалість, зухвалість, байдужість, лихослів'я [7, с. 1]. Подолання цієї кризи можливе шляхом особистісно зорієнтованого підходу до особистості, стратегічного плану отримання додаткової освіти на етапі кризи професійного самовизначення, розвитку стресостійкості, навчання навичкам самопідтримки, пошуку близьких друзів та супутника життя.

Криза молодості «сім'я, покликання» (приблизно 27-33 роки) можна охарактеризувати як переоцінку життєвих уявлень, цінностей, критичне переусвідомлення та пошук власного «Я», самовизначення в нових обставинах життя 3 урахуванням реальних можливостей і індивідуальних здібностей. У процесі цієї кризи закінчується освоєння нових способів взаємодії і починається розвиток індивіда всередині спільноти. Ïї позитивна симптоматика проявляється у відчутті необхідності досягнення нових висот, прагненні до безпеки і стабільності, політичній активності та побудові нового світогляду, розвитку навички організації широкої допомоги, вдосконаленні себе як фахівця i сім'янина. Негативні симптоми кризи: соціальна ізоляція, заглиблення в свою роботу, прагнення до самотності, егоїзм, відчуття пригніченості та відстороненості. Одним із перших цю кризу описав Е. Еріксон як дихотомію «близькість - ізольованість». Науковець доводить, що у процесі негативного вирішення кризи людина прагне до ізольованості та уникає інтимних стосунків та близькості [12]. Подолання цієї кризи можливе шляхом формування життєстійкості й опанування стратегією розв'язання складних життєвих ситуацій, побудови часової перспективи, знаходження нових обов'язків, стимулювання інтег- рації особистості, пошуку нових можливостей реалізувати свій потенціал.

Найхарактернішою для дорослого віку є «криза середини життя» «визнання» (39-45 років). Підсумовуючи дослідження науковців у вітчизняній психології щодо переживання кризи середини життя, Л. Гресь характеризує іiї зміною соціального та психологічного простору в житті людини (Г. Абрамова), підбиттям підсумків і звільненням від ілюзій (Б. Братусь, О. Хухлаєва), усвідомленням «розриву» особистого і загальнолюдського сенсу життя (В. Слободчиков), трансформацією образу «Я» та системи відносин (Б. Братусь, В. Слободчиков), нереалізованою суб'єктністю, відсутністю втілення програми життєвої перспективи (Р. Ахмеров, М. Срмолаєва) тощо. Автор доводить, що вікові кризи дорослості переважно зумовлені фізіологічними характеристиками (хвороби, гормональний дисбаланс), зовнішніми умовами (зміна вимог та очікувань культурного та соціальноекономічного середовища), змінами в психологічному віці та гендерними змінами [3]. І. Тичина вважає, що переживаючи кризу «середини життя», людина ще має час змінити свій життєвий шлях, реалізувати свої потенції, здійснити головний вчинок, який надасть сенс всьому іï існуванню $[11$, с. 35]. Зміст цієї кризи, за Е. Еріксоном, полягає у «творчій активності - зосередженості на собі» [12]. Позитивні симптоми кризи: критична переоцінка свого життя та його сенсу, колективна творчість, задоволеність життям у процесі реалізації власних здатностей, звільнення від впливу інших людей та встановлення власної ідентичності. Негативні симптоми кризи: відсутність програми життєвої перспективи, ослаблення внутрішньосімейних зв'язків, усвідомлення втрати молодості, погіршення фізичного стану та здоров'я, недостатня реалізованість, схильність до депресії, зосередженість на собі. Шляхами виходу з «кризи середини життя» можна вважати корекцію та перегляд життєвих планів, розробку конкретної стратегії життя, його особистісно-змістову перебудову 3 урахуванням особистісних уподобань і здібностей, розвиток творчих здібностей, зміну відносин «Я» і зобов'язань до інших людей, набуття своєї нової ідентичності.

Криза зрілості «наставництво» (55-65 років), пов'язана 3 відходом від своїх звичних соціальних зв'язків і професійної діяльності, оцінкою сенсу прожитого життя. Змістом цієї кризи, за Е. Еріксоном, $є$ «цілісність особистості - відчай» [12]. Позитивні симптоми: найвищі соціальні досягнення і отримання авторитету, якість та оригінальність особистого досвіду, усвідомлення життєвого шляху, передача досвіду молоді. Негативними симптомами цієї кризи Т. Дзюба, О. Коваленко вважають наступні прояви: порушується звичний режим життя людини; змінюється ii соціальний статус (з працівника вона стає пенсіонером); поступово віддаляються діти та онуки; прискорюється біологічне старіння, бо активізується деградація у різних системах організму; погіршується 
матеріальний стан; втрачаються близькі люди (смерть чоловіка, дружини) [5, с. 169]. Шляхами подолання цієї кризи є прийняття свого життєвого шляху таким, яким він $\epsilon$, вибудовування компенсаторних механізмів та подолання факторів ризику (хронічних, соматичних та невротичних розладів), активна участь у громадській діяльності та наставництво молоді.

Ураховуючи сучасні досягнення психології, останнім часом набувають популярності різні центри 3 означенням «кризовий», а саме: Український кризовий медіа-центр (УКМЦ); «Центр кризової допомоги для дівчат та молодих жінок у складних життєвих обставинах», Кризовий центр медико-психологічної допомоги Інституту психології імені Г. С. Костюка НАПН України та Національного медичного університету імені О. О. Богомольця та ін. Ці заклади спеціалізуються на визначенні шляхів подолання кризових ситуацій та роботі з людьми в період різних криз. У сучасних компаніях існують посади кризових менеджерів, які сприяють стабілізації ситуації в фірмах і накопичення позитивних змін у період кризи з метою отримання досвіду, нових знань, умінь і розуміння ситуації.

\section{ЛІТЕРАТУРА}

1. Варбан Є. О. Життєва криза: поняття, концепції та прояви / С. О. Варбан // Збірник наукових праць Кам'янець Подільського національного університету імені Івана Огієнка, Інституту психології ім. Г. С. Костюка АПН України. - 2010. - Вип.10. - С. 120-133.

2. Василюк Ф. Е. Типология переживания различных критических ситуаций / Ф. Е. Василюк // Психологический журнал. -1995. - №5. - Т.16. - С. 104-114.

3. Гресь Л. О. Наукові підходи до аналізу чинників перебігу кризи середини життя / Л. О. Гресь // Вісник Харківського національного педагогічного університету імені Г.С. Сковороди (Серія: «Психологія»). - 2014. - Т. 1. - № 44. - Т. 6. - С. 59-65.

4. Гречаник О. Акмеологічний супровід учителя в періоди вікових криз професійного становлення / О. Гречаник // Науковий вісник Східноєвропейського національного університету імені Лесі Українки. 2014. - Вип. 8. - С. 35-40.

5. Дзюба Т. М. Психологія дорослості з основами геронтопсихології: навч. посіб. для студентів вищих навчальних закладів / Т. М. Дзюба, О. Г. Коваленко; за ред. проф. В. Ф. Моргуна. - П., 2013. - $172 \mathrm{c}$.

6. Моргун В. Ф. Превентивно-профілактичний психологічний супровід професійної орієнтації на

\section{REFERENCES}

1. Varban, Ye. O. (2010). Zhyttieva kryza: poniattia, kontseptsii ta proiavy [Life crisis: concepts and manifestations]. Zbirnyk naukovykh prats Kamianets
Отже, проведений аналіз кризових явищ у розвитку особистості дав можливість дійти висновку, що вікові життєві кризи належать до нормативних процесів, спонукають до особистісного розвитку. Цей феномен науковці розглядають як соціальнопсихологічну ситуацію, що має свої суб'єктивні та об'єктивні характеристики; різкий, крутий злам в житті, що змінює його форму та напрямок; стан, що виникає, коли особистість зустрічається з перешкодами життєво важливих цілей; тривалий внутрішній конфлікт із приводу життя в цілому та його сенсі; емоційну реакцію людини на загрозливу ситуацію, що спричиняє певні переживання тощо. Вікові життєві кризи обумовлюють завершення певного етапу життя та перехід до нового етапу розвитку індивіда. Грунтовний аналіз психологічної літератури дав можливість виокремити такі основні кризи дорослого віку: криза входження у дорослість «власне Я та його реалізація» (20-23 роки); криза молодості «сім'я, покликання» (27-33 роки); криза середини життя «визнання» (39-45 років); криза зрілості «наставництво» (55-65 років). Подальших досліджень потребує уточнення періодизації психічного розвитку особистості в дорослому віці з урахуванням наявних криз у цей віковий період.

основі багатовимірної теорії особистості / В. Ф. Моргун // Психологічні перспективи. - 2010. - Вип. 16. С. $205-216$.

7. Поліщук В. М. Криза входження у дорослість як перехідний період від юнацького віку до вступу у дорослість / В. М. Поліщук // Практична психологія та соціальна робота. - 2012. - № 9. - С. 1-6.

8. Солдатова Е. Л. Структура и динамика нормативного кризиса перехода к взрослости: монография / Е. Л. Солдатова. - Челябинск: Изд-во ЮУрГУ, 2007. - 267 с.

9. Солодникова И. В. Развитие человека в зрелости как проблема гуманитарных наук / И. В. Солодникова // Общественные науки и современность. - 2001. - № 2. - С. 147-157.

10. Титаренко Т. Життєві кризи: технології консультування. Перша частина / Т. Титаренко. - К. : Главник, 2007. - 144 с.

11. Тичина I. М. Творчість як засіб подолання життєвої кризи у дорослому віці / I. М. Тичина // Духовність українства: Збірник наукових праць: Випуск другий / ред. кол. Ю. Білодід та ін. - Житомир: Редакційно-видавничий відділ ІПСТ, - 2000. - С. 33-36.

12. Эриксон Э. Х. Восемь возрастов человека / Э. Х. Эриксон // Детство и Общество. - Изд. 2-е, переработанное и дополненное, пер. Алексеева А. А. СПб.: «Речь». - 2002. - С. 235-259.

Podilskoho natsionalnoho universytetu imeni Ivana Ohiienka, Instytutu psykholohii im. H. S. Kostiuka APN Ukrainy - Collection of scientific works of Ivan Ohiienko 
Kamianets Podilskyi national university, G. S. Kostyuk Institute of Psychology of NAES of Ukraine, 10, 120-133 [in Ukrainian].

2. Vasyliuk, F. E. (1995). Typologiya perezhyvaniya razlichnykh kriticheskikh situatsyi [Typology of experiencing different critical situations]. Psykhologicheskiy zhurnal - Psychological journal, 5, 104-114. (Vol. 16). [in Russian].

3. Hres, L. O. (2014). Naukovi pidkhody do analizu chynnykiv perebihu kryzy seredyny zhyttia [Scientific approaches to the analysis of factors of experiencing middle-age crisis]. Visnyk Kharkivskoho natsionalnoho pedahohichnoho universytetu imeni H.S. Skovorody Bulletin of H. S. Skovoroda Kharkiv national pedagogical university, 44, 59-65 [in Ukrainian].

4. Hrechanyk, O. (2014). Akmeolohichnyi suprovid uchytelia $\mathrm{v}$ periody vikovykh kryz profesiinoho stanovlennia [Acmeological support for a teacher during periods of professional crisis]. Naukovyi visnyk Skhidnoievropeiskoho natsionalnoho universytetu imeni Lesi Ukrainky - Scientific bulletin of Lesya Ukrainka EastEuropean national university, 8, 35-40 [in Ukrainian].

5. Dziuba, T. M., Kovalenko, O. H. (2013). Psykholohiia doroslosti z osnovamy herontopsykholohii: navch. posib. dlia studentiv vyshchykh navchalnykh zakladiv [Psychology of adulthood with the bases of gerontopsychology: textbook for university students]. Morhun, V. F. (Ed.). [in Ukrainian].

6. Morhun, V. F. (2010). Preventyvnoprofilaktychnyi psykholohichnyi suprovid profesiinoi oriientatsii na osnovi bahatovymirnoi teorii osobystosti [Preventive psychological support of professional orientation on the basis of multi-dimensional theory of personality]. Psykholohichni perspektyvy - Psychological pro- spects, 16, 205-216 [in Ukrainian].

7. Polishchuk, V. M. (2012). Kryza vkhodzhennia $\mathrm{u}$ doroslist yak perekhidnyi period vid yunatskoho viku do vstupu u doroslist [Crisis of entering the adulthood as a transition period from youth to adulthood]. Praktychna psykholohiia ta sotsialna robota - Practical psychology and social work, 9, 1-6 [in Ukrainian].

8. Soldatova, E. L. (2007). Struktura i dinamika normativnogo krizisa perekhoda $k$ vzroslosti: monografiya [Structure and dynamics of crisis traisition to adulthood: monograh]. Chelyabinsk: Izd-vo YuUrGU [in Russian].

9. Solodnikova, I. V. (2001). Razvitie cheloveka v zrelosti kak problema gumanitarnykh nauk [Development of a person in middle years as an issue for humanities]. Obshchestvennye nauki i sovremennost - Social sciences and modernity, 2, 147-157 [in Russian].

10. Tytarenko, T. (2007). Zhyttievi kryzy: tekhnolohii konsultuvannia. Persha chastyna [Life crises: technologies of consulting. The first part]. Kyiv: Hlavnyk [in Ukrainian].

11. Tychyna, I. M. (2000). Tvorchist yak zasib podolannia zhyttievoi kryzy u doroslomu vitsi [Creativity as a means for overcoming life crisis in adulthood]. $D u$ khovnist ukrainstva: Zbirnyk naukovykh prats - Ukrainian spirituality: collection of scientific works, 2, 33-36. Bilodid, Yu. (Ed.). Zhytomyr: Redaktsiino-vydavnychyi viddil IPST [in Ukrainian].

12. Erikson, E. Kh. (2002). Vosem vozrastov cheloveka [Eight age periods of a human being]. Detstvo $i$ Obshchestvo - Childhood and society. $2^{\text {nd }} \mathrm{ed}$. rev. Alekseeva, A. A. (transl.). Saint Petersburg: «Rech» [in Russian].

Вера Юрьевна Помилуйко, кандидат психологических наук, докторант, Национальный педагогический университет имени М. П. Драгоманова, ул. Пирогова, 9, г. Киев, Украина

\section{ПУТЬ К ЗРЕЛОСТИ ЧЕРЕЗ ЖИЗНЕННЫЕ КРИЗИСЫ ВЗРОСЛЫХ}

Цель статьи состоит в теоретическом анализе векторов развития возрастных кризисов личности во взрослом возрасте, выделении положительной и негативной симптоматики основных кризисов взрослости. Выделены следующие основные виды кризиса взрослого возраста: кризис вхождения во взрослость (20-23 года); кризис молодости (27-33 года); кризис середины жизни (39-45 лет); кризис зрелости (55-65 лет). Кризис вхождения во взрослость «собственное Я и его реализация» - первый нормативный кризис взрослого возраста. Положительными симптомами этого кризиса являются гордость за собственные достижения, навыки самоконтроля, стремление к самостоятельности, исполнительность, оптимизм. Негативными симптомами являются раздражительность, хитрость, индивидуализм, приспособляемость; высокомерие, зависть, корысть; небрежность, дерзость, равнодушие, сквернословие. Преодоление этого кризиса возможно путем личностно ориентированного подхода к личности, стратегического плана получения дополнительного образования на этапе кризиса профессионального самоопределения, поиска близких друзей и спутника жизни. Кризис молодости «семья, призвание» можно охарактеризовать как переоценку жизненных представлений, ценностей, критическое переосмысление и поиск собственного «Я». Положительная симптоматика проявляется в ощущении необходимости достижения новых высот, стремлении к безопасности и стабильности, политической активности, совершенствовании себя как специалиста и семьянина. Негативные симптомы: социальная изоляция, углубление в работу, стремление к одиночеству, эгоизм, чувство подавленности и отстраненности. Преодоление этого кризиса возможно путем формирования жизнестойкости и освоения стратегией решения сложных жизненных ситуаций, 
поиска новых возможностей реализовать свой потенциал. Характерной для взрослого возраста является «кризис середины жизни» - «признание». Положительные симптомы: критическая переоценка своей жизни и ее смысла, коллективное творчество, удовлетворенность жизнью в процессе реализации собственных способностей. Негативные симптомы: отсутствие программы жизненной перспективы, ослабление внутрисемейных связей, осознание потери молодости, ухудшение физического состояния. Путями выхода из «кризиса середины жизни» можно считать коррекцию и пересмотр жизненных планов, развитие творческих способностей, изменение отношений «Я» и обязательств к другим людям. Кризис зрелости - «наставничество» - связан с уходом от своих привычных социальных связей и профессиональной деятельности, оценкой смысла прожитой жизни. Положительные симптомы: высокие социальные достижения и авторитет, осознание жизненного пути, передача опыта молодежи. Негативные симптомы: нарушается привычный режим жизни человека; меняется его социальный статус (с работника она становится пенсионером); постепенно удаляются дети и внуки; ускоряется биологическое старение; ухудшается материальное положение; теряются близкие люди (смерть мужа, жены). Путями преодоления этого кризиса является принятие своего жизненного пути таким, какой он есть, выстраивание компенсаторных механизмов и преодоление факторов риска (хронических, соматических и невротических расстройств), активное участие в общественной деятельности и наставничество молодежи. Выявлено, что в описании кризисов взрослого периода центральное место отведено пересмотру основных целей и жизненных ориентиров личности, что является общей характеристикой кризисов взрослости.

Ключевые слова: возрастные кризисы, векторы развития, взрослость, переживания, разновидности жизненных кризисов, фрустрации.

Vira Pomyluiko,

PhD (Candidate of Psychological Sciences), doctoral student, National Pedagogical Dragomanov University, 9, Pyrohova Str., Kyiv, Ukraine

\section{WAY TO MATURITY THROUGH LIFE CRISES OF ADULTHOOD}

The article deals with the theoretical review of personality' age crises in adulthood, allocation of positive and negative characteristics of the main adulthood crises. The following crisis types have been distinguished: crisis of becoming an adult (20-23 years); youth crisis (27-33); middle-age crisis (39-45); maturity crisis (55-65 years). The first type of crisis "self-realization" is the first normative crisis of a human being, which has the following positive characteristics: self-pride, skills of self-control, desire for independence, optimism; and the following negative symptoms: impatience, hypocrisy, envy, greed, etc. It is possible to overcome this crisis by personally-centered approach to an individual, by receiving another degree at the background of professional crisis, by search for good friends and life partner. The youth crisis is considered as reassessment of life attitudes, values, self-search. Positive symptoms: the necessity of achieving new goals, striving for stability, political activity, etc. Negative characteristics: social isolation, desire for loneliness, depression, selfishness. One can overcome this crisis by means of searching for new opportunities to reach the potential. Adulthood is characterized by the middle-age crisis - recognition. Positive features: critical reassessment of one's life and its sense, satisfaction with life. Negative features: the absence of project of life, worsening of health, realization of ageing. The development of creative abilities, reconsideration of life values and goals can help to overcome this crisis. The last crisis (maturity crisis) is associated with the retirement, the assessment of "vita peracta". Positive symptoms: high social achievements, sharing the experience with youth. Negative characteristics: change of a social status, death of close friends and relatives. One should accept his/her life journey as it is, taking part in social activities, etc. to overcome it. Thus, the reconsidering of life goals and life orientations occupies the central position in the description of the adulthood period crises, which is regarded as the common characteristics for all types of crises.

Keywords:age crises, branches of the development, adulthood, experiencing, types of life crises, frustration.

Подано до редакиії 01.09.2016 